\title{
Effects of nickel oxide nanoparticles on survival, reproduction, and oxidative stress biomarkers in the marine calanoid copepod Centropages ponticus under short-term exposure
}

\author{
Djebbi Emna ${ }^{1,{ }^{*}}$, Bonnet Delphine ${ }^{2}$, Pringault Olivier ${ }^{3}$, Tlili Khawla ${ }^{4}$, Yahia Mohamed Néjib Daly ${ }^{5}$
}

${ }^{1}$ Faculty of Sciences of Bizerte, Carthage University, 7021, Zarzouna, LR18ES41 (Tunis El Manar University), 1082, Tunis, Tunisia

2 Univ. Montpellier, CNRS, Ifremer, IRD, MARBEC, Montpellier, France

${ }^{3}$ Aix Marseille Univ, Université de Toulon, CNRS, IRD, MIO UM 110, 13288, Marseille, France

${ }^{4}$ LEBPAO, Faculty of Sciences of Tunis, University of Tunis, El Manar, FSB, Zarzouna, 7021, Bizerte, Tunisia

5 Department of Biological and Environmental Sciences, College of Arts and Sciences, Qatar University, PO Box 2713, Doha, Qatar

* Corresponding author : Emma Djebbi, email address : amnadjebbi@gmail.com

\begin{abstract}
:
Excessive use of nickel oxide nanoparticles (NiO NPs) in various industrial and commercial products can lead to various negative effects in human and environmental health due to their possible discharge into the environment. Nerveless, information about their ecotoxicological effects on marine organisms are lacking. Copepods are good ecotoxicological models because of their high sensitivity to environmental stress and their key role in the marine food webs. In this study, $48 \mathrm{~h}$ acute tests were conducted on the marine planktonic copepod Centropages ponticus to assess lethal and sublethal toxicities of NiO NPs. The results revealed LC50 ( $48 \mathrm{~h})$ of $4 \mathrm{mg} / \mathrm{L}$ for adult females. Aggregation and settling of NiO NPs were observed at concentrations $\geq 2 \mathrm{mg} / \mathrm{L}$. Exposure to sublethal concentrations ( $\geq 0.02 \mathrm{mg} / \mathrm{L}$ for $48 \mathrm{~h}$ ) had significant negative effects on reproductive success in C. ponticus. Egg production after $24 \mathrm{~h}$ and $48 \mathrm{~h}$ decreased by $32 \%$ and $46 \%$, respectively at $0.02 \mathrm{mg} / \mathrm{L}$ and $70 \%$ and $82 \%$, respectively, at $2 \mathrm{mg} / \mathrm{L}$. Hatching success was reduced by $70 \%$ and $79 \%$ at $2 \mathrm{mg} / \mathrm{L}$ for eggs produced after $24 \mathrm{~h}$ and $48 \mathrm{~h}$ respectively. Antioxidant enzymatic activity increased significantly with NiO NP concentration and time, indicating that NiO NPs can cause oxidative stress in C. ponticus even under short-term exposure, while significant inhibition of acetylcholinesterase activity at $2 \mathrm{mg} / \mathrm{L}$ after $48 \mathrm{~h}$ suggests neurotoxic effects of NiO NPs.
\end{abstract}

Keywords : Metal oxide nanoparticle, Copepods, Acute toxicity test, Egg production, Egg hatching success, Antioxidant enzymes 


\section{Introduction}

Nanoparticles (NPs) represent a serious environmental threat due to their toxicity and persistence (Geissen et al. 2015). According to the British Standards Institution, these compounds are defined as discrete pieces of material with all three external dimensions in the nanoscale (size $<100 \mathrm{~nm}$ ). Size, shape, chemical composition and structure of particle are main factors which determine the nanoparticle properties (optical, electrical, and magnetic properties) (Khan et al. 2019). Based on their chemical composition, NPs can be divided into various groups: e.g., metallic, polymeric metallic oxide, semiconductor, and metallic oxide nanoparticles. Among the metallic oxide group, nickel oxide nanoparticles (NiO NPs) have widespread use in many industrial and commercial products (e.g., solar cells, lithium-ion batteries, resistive random-access memory, and biosensors), due to their magnetic properties (Tadik et al. 2015). There are also multiple medical and biotechnological applications of NiO NPs, such as remediation of heavy metal contaminated water and enhancement of biogas production from macrophytes of wastewater treatment plants (Mahmoud et al. 2015; Salama et al. 2020). A recent study has reported an annual production of NiO NPs of 20 tons only in the United states (Gomes et al. 2019) which increases progressively the levels of NiO NPs exposure as stated by Avila-Arias et al. (2019). The excessive use of NiO NPs leads to their possible widespread distribution in terrestrial, estuarine, freshwater, and marine ecosystems through industrial and domestic wastewaters and aerial deposition (Wiesner et al. 2006). Despite the number of studies on NiO NPs, the environmental concentrations and distribution in field environmental matrices (water, sediment, and biota) have not yet been explored. Research investigating environmental nanoparticle concentrations in aquatic ecosystems has shown that these compounds are detectable in aquatic matrices at concentrations up to $\mu \mathrm{g} / \mathrm{L}$ (Zhang et al. 2019). Overall, the behavior of nanoparticles varies with the environmental matrix (water, sediment, soil, etc.). For NiO NPs, aggregation behavior in seawater has been observed due to their low solubility and high stability (Gong et al. 2016; Oukarroum et al. 2017).

There are numerous concerns about the risks posed by nanoparticle pollution to the environment and human health (Ates et al. 2016; Oukarroum et al. 2017). Previous laboratory studies have shown that NiO NPs have the potential to cross biological membranes and to accumulate in target tissues, causing harmful toxic effects (Ates et 

al. 2016; Oukarroum et al. 2017). In addition, Ates et al. (2016) showed that NiO NP accumulation increases with exposure concentration and duration. Acute and chronic exposures to NiO NPs have been associated with mortality effects on aquatic organisms, depending on species sensitivity (Kovrižnych et al. 2014; Oukarroum et al. 2017). NiO NPs can limit cell division, as observed for the green algae Chlorella vulgaris, and can also limit reproduction in zebrafish (Danio rerio) (Oukarroum et al. 2017). Moreover, NiO NPs have been shown to be associated with cytotoxic and genotoxic effects even under acute exposure in algae, rats, and human cells (Ada et al. 2010; Oukarroum et al. 2017). The toxicity of nanoparticles is influenced by their intrinsic characteristics (size, surface area, chemical composition, crystal structure, shape, etc.) and their behavior (aggregation, dissolution) (Sukhanova et al. 2018). Studies examining the toxicity mechanism of NiO NPs have found that they cause toxicity in aquatic organisms by induction of oxidative stress through generation of high levels of reactive oxygen species (i.e., hydrogen peroxide: $\mathrm{H}_{2} \mathrm{O}_{2}$, the superoxide anion: $\mathrm{O}^{2-}$, and the hydroxyl radical: $\mathrm{OH}$ ) and disruption of antioxidant enzymes such as glutathione (GSH), as observed in algal cells (Manke et al. 2013; Oukarroum et al. 2017). Disruption of the antioxidant system can be associated with major risks, such as neurotoxicity, lipid peroxidation, and apoptosis (Ada et al. 2010; Ates et al. 2016).

Despite the known toxicity of NiO NPs, marine species have received little attention, as noted by Gong et al. (2019), in comparison with freshwater species (Oukarroum et al. 2017; Sousa et al. 2018a, b). Thus, ecotoxicological studies of the effects of $\mathrm{NiO}$ NPs on marine organisms are needed. Copepods may be interesting marine biological models for such studies, considering their essential role in marine ecosystems as main secondary producers in food webs and as vital links between phytoplankton and higher trophic levels, to which they transfer carbon and energy (Jayalakshmi and Santhanam 2019). In addition, copepods can represent a pathway for contaminant entry for higher trophic links (Lauer and Bianchini 2010; Cailleaud et al. 2011). Moreover, copepods are known as good bio-indicators of ecosystem pollution, because of their sensitivity to several environmental disturbances (Bianchi et al. 2003; Hussain et al. 2020). These organisms can develop adaptive responses to oxidative stress using a sophisticated biochemical defense mechanism (Kim et al. 2014). The marine calanoid copepod Centropages ponticus is a cosmopolite species and has been used previously as an experimental model for ecotoxicological tests due to its short 
life cycle, its small size, and its high sensitivity to contaminants such as metals (Ensibi et al. 2015; Ensibi and Yahia 2017). In this study, we conducted acute toxicity tests to investigate the lethal and sublethal effects of NiO NPs on C. ponticus under short-term exposure. Indeed, acute tests mimic the effects of NPs under accidental and short-term release into the environment. In addition, due to their lifestyle and ability to swim, planktonic organisms, like copepods, should experience shorter time exposure than benthic organisms for example. Moreover, due to their rapid transformation behavior, NPs, such as NiO NPs, aggregate in marine waters and deposit in the sediment which reduces their bioavailability for aquatic pelagic organisms and raises the risk for benthic organisms (Miglietta et al. 2015). Finally, results from acute tests allow selecting a range of NiO NPs concentrations to be used in sublethal tests. Copepod reproductive traits and molecular responses (e.g., egg production rate, hatching success, nauplius survival rate, biomarkers, and genomic profiles) are reliable tools to evaluate the impacts of different types of environmental contaminants (Zhou et al. 2018; Hussain et al. 2020). Egg production rate (EPR) and hatching success (HS) were studied here as sub-lethal endpoints under different $\mathrm{NiO}$ NPs concentrations. The response of the antioxidant defense system to NiO NPs was investigated by determining the levels of some antioxidant enzymes such as catalase (CAT), superoxide dismutase (SOD), and glutathione S-transferase (GST), and the level of acetylcholinesterase (AChE) as a neurotoxicity indicator of oxidative damage. This study is the first to focus on marine planktonic copepods, with the aim of providing new knowledge to clarify the mechanisms behind NiO NPs toxicity in this species.

\section{Materials and methods}

\section{Copepod sampling and algal cultures}

Copepods were captured in the Bizerte channel, north of Tunisia $\left(37^{\circ} 16^{\prime} 1^{\prime \prime} \mathrm{N}\right.$; 9॰52’50”E), using a WP2 plankton net (200 $\mu \mathrm{m}$ mesh size) drawn by vertical tows. Sampling was carried out during summer and autumn 2017. Copepods were placed in cold boxes and immediately transported to the laboratory. Identification of $C$. ponticus was performed based on their morphological and swimming characteristics, using a Leica MZ125 stereomicroscope (Soler et al. 1988). Prior to exposure to nanoparticles, adult females of $C$. ponticus were acclimated in seawater at $23{ }^{\circ} \mathrm{C}$ and 
$37 \mathrm{psu}$ for $24 \mathrm{~h}$, and fed the marine microalga Isochrysis galbana. Culture of this algal species was performed in filtered seawater $(0.2 \mu \mathrm{m})$ with $\mathrm{f} / 2$ enriched media at $20{ }^{\circ} \mathrm{C}$ and on a 12-:12-h light: dark cycle. All glassware was soaked in 10\% nitric acid $\left(\mathrm{NHO}_{3}\right)$ for $24 \mathrm{~h}$ and autoclaved at $121{ }^{\circ} \mathrm{C}$ for $15 \mathrm{~min}$ before use.

\section{Nickel nanopowder preparation}

Nickel oxide nanoparticles (product reference 637130) were purchased from Aldrich Sigma Chemicals. A test solution was freshly prepared before the beginning of the experiment and then diluted in filtered seawater. The NiO NPs were dispersed in ultra-pure water to obtain a concentration of $100 \mathrm{mg} / \mathrm{L}$ and the suspension was then sonicated for $20 \mathrm{~min}$ at $4{ }^{\circ} \mathrm{C}(40 \mathrm{KHz}, 100 \mathrm{~W})$. The particle size of the NiO NPs was $\leq 50 \mathrm{~nm}$ with purity $>99.8 \%$ and the particle morphology was cubic, according to the supplier (https://www.sigmaaldrich.com/catalog/product/aldrich/637130?lang=en\&region=TN). The size of these nanoparticles (before its dispersion in ultrapure water or biological test media (powder form) was confirmed $(<50 \mathrm{~nm}$ ) by Sousa et al. (2018a) using transmission electron microscopy. Right after dispersion in deionized water, Sousa et al. (2018a) reported a main hydrodynamic size of $342 \mathrm{~nm}$ which exceeds $1000 \mathrm{~nm}$ after $24 \mathrm{~h}$ and displays a negative zeta potential value.

Previous physical characterizations of other manufactured NiO NPs, different from the one we used, in seawater showed that these NPs display negative zeta potential value, non-uniform morphology and a size > $100 \mathrm{~nm}$ revealing their tendency to aggregate in seawater (Gong et al. 2011; Ates et al. 2016; Gong et al. 2019).

\section{Toxicity test procedures}

\section{Acute lethal toxicity test}

To determine the lethal toxicity (median lethal concentration, $\mathrm{LC}_{50}$ ) of NiO NPs, 48-h acute toxicity tests with adult females of $C$. ponticus were performed according to ISO 14669:1999 revised 2015 and Zhou et al. (2016), with some modifications. All glass beakers were washed with $10 \% \mathrm{NHO}_{3}$ and rinsed three times with deionized water. For each NiO NP concentration tested, triplicate groups of 10 adult females were placed in $150 \mathrm{~mL}$ glass beakers containing $100 \mathrm{~mL}$ of the test solution. Five $\mathrm{NiO}$ NP concentrations were tested: $0,0.5,1,5,10$, and $50 \mathrm{mg} / \mathrm{L}$. Photoperiod was 12-:12- 
h light: dark cycle, salinity was $37 \mathrm{psu}$, and temperature was fixed at $23{ }^{\circ} \mathrm{C}$. During the experiment, the copepods were not fed. Mortality was recorded after $24 \mathrm{~h}$ and $48 \mathrm{~h}$ of exposure. A copepod was considered dead if no swimming or appendage movements were observed for 10 seconds.

\section{Acute sub-lethal toxicity tests}

Once the $\mathrm{LC}_{50}(48 \mathrm{~h})$ for NiO NPs had been determined, acute sub-lethal toxicity tests were performed using $\mathrm{NiO} \mathrm{NP}$ concentrations below the $\mathrm{LC}_{50}$ value. Adult females of C. ponticus were exposed to four sub-lethal concentrations: $50 \%, 5 \%, 0.5 \%$, and $0.05 \%$ of the $48 \mathrm{~h} \mathrm{LC}_{50}$ to study $\mathrm{NiO}$ NPs effect on reproduction and oxidative stress.

\section{Reproduction}

Reproductive toxicity tests were conducted on adult females according to Zhou et al. (2016) with few modifications, and then EPR and HS were monitored over $48 \mathrm{~h}$ of $\mathrm{NiO}$ NPs exposure. Three replicates were prepared for each concentration. Each replicate comprised 3-4 ovigerous females of $C$. ponticus incubated in a $150 \mathrm{~mL}$ glass beaker with $100 \mathrm{~mL}$ of filtered seawater. To prevent cannibalism, the females were separated from their eggs using a Perspex ${ }^{\circledR}$ chamber with a $200 \mu \mathrm{m}$ mesh false bottom. The experiments were run at $37 \mathrm{psu}$ and $23{ }^{\circ} \mathrm{C}$ in an incubator under a fixed 12-:12-h light:dark cycle. After $24 \mathrm{~h}$, the females from each replicate were gently transferred to a new glass beaker containing fresh test solution, to measure EPR after $48 \mathrm{~h}$. The number of eggs spawned was counted every $24 \mathrm{~h}$ under a Leica binocular microscope for each condition, and EPR was expressed as number of eggs spawned per female per day (eggs/female/day). To monitor the effect of exposure to NiO NPs on hatching success, the eggs spawned after $24 \mathrm{~h}$ and $48 \mathrm{~h}$ were then incubated for 48 $h$ in the same solution of NiO NPs. The numbers of nauplii and unhatched eggs in each treatment were determined at the end of the incubation period.

\section{Oxidative stress}

Prior to biomarker analysis, C. ponticus adult females were exposed for $48 \mathrm{~h}$ to the same range of $\mathrm{NiO} \mathrm{NP}$ concentrations as used in the reproduction tests. The experiments were conducted in triplicate for each treatment and control, following the protocol of Fossi et al. (2001). Each replicate received 150 individuals, which were placed in a $1 \mathrm{~L}$ glass beaker filled with filtered seawater. The temperature and salinity 
were $23{ }^{\circ} \mathrm{C}$ and $37 \mathrm{psu}$, respectively. A light regime of 12-:12-h light: dark cycle was maintained. The experiment was run for $48 \mathrm{~h}$ and the organisms were not fed. A sample of 75 copepods was taken every $24 \mathrm{~h}$ from each replicate per treatment and immediately frozen at $-80^{\circ} \mathrm{C}$ until measurement of biomarkers.

\section{Biomarker analysis}

\section{Total protein}

In order to determine the protein content in copepods, samples of $C$. ponticus were homogenized at $4{ }^{\circ} \mathrm{C}$ using an ultratorax in a buffer solution containing tris base (20 $\mathrm{mM})$, EDTA $(1 \mathrm{mM})$, dithiothreitol $(1 \mathrm{mM})$, sucrose $(500 \mathrm{mM})$, and $\mathrm{KCl}(150 \mathrm{mM})$ adjusted to $\mathrm{pH} 7.6$ at a ratio of 1-4 (w/v) according to the protocol of Pinho et al. (2005). The homogenate was then centrifuged at $9000 \mathrm{~g}$ for $30 \mathrm{~min}$ at $4{ }^{\circ} \mathrm{C}$. The resulting supernatant was divided into several aliquots, which were stored at $-80{ }^{\circ} \mathrm{C}$ until total protein and biomarker analysis. Total proteins were quantified by the Bradford method (Bradford 1976) using $50 \mu \mathrm{L}$ sample protein and bovine serum albumin as the standard. The assay was performed in a microplate reader using 96 well plates. Protein concentrations were expressed in $\mathrm{mg} / \mathrm{L}$ after spectrophotometric quantification at $595 \mathrm{~nm}$.

\section{Superoxide dismutase (SOD) activity measurement}

Superoxide dismutase activity was measured based on the method of McCord and Foridovich (1996). In brief, $1960 \mu \mathrm{L}$ of $\mathrm{Na}_{2} \mathrm{CO}_{3} / \mathrm{NaHCO}_{3}(50 \mathrm{mM})(\mathrm{pH}=10.2)$ were combined with $10 \mu \mathrm{L}$ of catalase bovine, $10 \mu \mathrm{L}$ of sample, and $20 \mu \mathrm{L}$ of epinephrine. Total SOD activity was measured at $480 \mathrm{~nm}$ using a spectrophotometer, and was expressed as SOD U/mg protein.

\section{Catalase (CAT) activity measurement}

Catalase is an enzyme that catalyzes the decomposition of $\mathrm{H}_{2} \mathrm{O}_{2}$ formed by SOD in molecular water $\left(\mathrm{H}_{2} \mathrm{O}\right)$ and molecular oxygen $\left(\mathrm{O}_{2}\right)$. Here, CAT activity was estimated according to Clairborne (1985), where the rate of disappearance of $\mathrm{H}_{2} \mathrm{O}_{2}$ is monitored by measuring the rate of decrease in $\mathrm{H}_{2} \mathrm{O}_{2}$ at $240 \mathrm{~nm}$ for $20 \mathrm{~min}$. In brief, $50 \mu \mathrm{L}$ of sample were added to $50 \mu \mathrm{L}$ of $30 \% \mathrm{H}_{2} \mathrm{O}_{2}$ and $950 \mathrm{~mL}$ of $75 \mathrm{mM}$ phosphate buffer at $\mathrm{pH}=7$. The results were expressed as CAT U/mg protein. 
252 Glutathionine activity was determined by measuring the conjugation of 1-chloro-2-4-

253

254

255

256

257

258

259

260

261

262

263

264

265

266

267

268

269

270

271

272

273

274

275

276

277

278

279

280

281

282 dinitrobenzene (CDNB) with GSH at $37{ }^{\circ} \mathrm{C}$. The rate of GSH decrease is directly proportional to the level of GST activity in the sample. A total of $50 \mu \mathrm{L}$ of sample was added to $50 \mu \mathrm{L}$ of CDNB and $100 \mu \mathrm{L}$ glutathione in $100 \mathrm{mM}$ phosphate buffer (100 mM) at pH 7.4 (Habig et al. 1974). The results were expressed as GST $\mathrm{nmol} / \mathrm{min} / \mathrm{mg}$ protein.

\section{Acetylcholinesterase measurement}

Measurement of AChE activity was carried out according to Ellman et al. (1961), with $3 \mathrm{mM}$ acetylthiocholine iodide (AcSCh) as substrate and $0.1 \mathrm{Mm}$ dithiobisnitrobenzoate (DTNB) as reagent, at a controlled temperature of $20{ }^{\circ} \mathrm{C}$. Absorbance was recorded at $410 \mathrm{~nm}$ for 15 min using $20 \mu \mathrm{L}$ of sample according to Fossi et al. (2001). AChE activity was expressed in nmol/min/mg protein.

\section{Data analysis}

The results from the lethal and sub-lethal tests are presented as means \pm their standard deviation. Statistical analyses of the data were performed using SPSS (version 18). The effects of the concentrations tested in each experiment were compared with those of controls using two-way ANOVA (time and treatment), followed by post-hoc Tukey's test. Data were log-transformed, if necessary, to meet the ANOVA assumption of normality and variance homogeneity. The level of significance was set at $p<0.05$. The median lethal concentration $\left(\mathrm{LC}_{50}\right)$ was calculated by probit analysis using SPSS.

\section{Results}

\section{Acute lethal toxicity test and aggregation behavior}

There was no mortality in the controls during the whole incubation period. The results of two-way ANOVA indicated a strong influence of both time and concentration on survival rate $(p<0.05)$ (Table 1$)$. They also showed a significant interaction between exposure time and $\mathrm{NiO} \mathrm{NP}$ concentrations $(p<0.05)$. The survival rate at concentrations ranging from 0.5 to $1 \mathrm{mg} / \mathrm{L}$ of NiO NPs was $\geq 90 \%$ over the exposure 
period. After $24 \mathrm{~h}$, the survival rate was $>90 \%$ at a concentration of $5 \mathrm{mg} / \mathrm{L}$ and $<50$ $\%$ at a concentration $\geq 10 \mathrm{mg} / \mathrm{L}$ relative to the control groups $(p<0.05)$. After $48 \mathrm{~h}$ of incubation, NiO NPs at concentrations greater than $1 \mathrm{mg} / \mathrm{L}$ induced a significant $(p<0.05)$ reduction in survival rate, which decreased from $90 \pm 1.7 \%$ at an NiO NPs concentration of $1 \mathrm{mg} / \mathrm{L}$ to $0 \%$ at $50 \mathrm{mg} / \mathrm{L}$. The calculated $\mathrm{LC}_{50}$ value for $24 \mathrm{~h}$ and 48 $\mathrm{h}$ of exposure was $13.83 \pm 2.3 \mathrm{mg} / \mathrm{L}$ and $4.07 \pm 0.5 \mathrm{mg} / \mathrm{L}$, respectively (Table 2 ).

During the acute toxicity tests, black aggregates visible to the naked eye appeared at the bottom of the beaker at NiO NPs concentrations ranging from 2 to $50 \mathrm{mg} / \mathrm{L}$ after $48 \mathrm{~h}$ of incubation. Microscope observations revealed similar aggregates of NiO NPs on the exoskeleton of $C$. ponticus (Fig. 1a, b).

\section{Effect on reproductive success}

The effects of NiO NPs on reproductive success in C. ponticus were assessed by monitoring EPR over $48 \mathrm{~h}$ and then determining HS (Fig. 2). For both parameters, no significant $(p>0.05)$ effect was observed at the lowest concentration of NiO NPs $(0.002 \mathrm{mg} / \mathrm{L})$ over $48 \mathrm{~h}$.

A significant $(p<0.05)$ influence of time exposure on EPR was observed for all $\mathrm{NiO}$ NPs treatments (Table 1). However, no significant $(p>0.05)$ interaction was observed between time exposure and NiO NPs concentration. For the control groups, EPR varied between $11.3 \pm 0.6$ eggs female ${ }^{-1}$ day $^{-1}$ at $24 \mathrm{~h}$ and $8.3 \pm 1.1$ eggs/female/day at 48 h. After $24 \mathrm{~h}$, a significant reduction in EPR $(p<0.05)$ was observed, to $7.5 \pm 1.5$ eggs/female/day at $0.02 \mathrm{mg} / \mathrm{L}$ and $3.3 \pm 0.3 \mathrm{eggs} /$ female/day at $2 \mathrm{mg} / \mathrm{L}$ of NiO NPs (Fig. 2a). After 48 h, EPR showed a continuous decrease, reaching $1.5 \pm 0.2$ eggs/female/day at the highest concentration $(2 \mathrm{mg} / \mathrm{L})$.

There was no significant effect of time exposure $(p>0.05)$ on HS for the different concentrations tested (Table 1). However, HS for eggs spawned after $24 \mathrm{~h}$ and $48 \mathrm{~h}$ decreased significantly $(p<0.05)$ with increasing NiO NPs concentrations $\geq 0.02 \mathrm{mg} / \mathrm{L}$. For the control groups, HS varied between $85.0 \pm 2.1 \%$ for eggs spawned after $24 \mathrm{~h}$ and $81.3 \pm 4.0 \%$ for eggs spawned after $48 \mathrm{~h}$. The lowest values of HS, observed at the highest NiO NPs concentration tested ( $2 \mathrm{mg} / \mathrm{L}$ ), were $24 \pm 7 \%$ and $16 \pm 2 \%$ for eggs spawned after $24 \mathrm{~h}$ and $48 \mathrm{~h}$, respectively (Fig. 2 b). For this endpoint measurement, no significant interaction was observed between time exposure and NiO NPs concentration (Table 1). 


\section{Effect of NiO NPs on oxidative stress}

In order to assess the mechanisms behind NiO NPs toxicity at cellular level, some oxidative enzymes (CAT, SOD, GST) and the neurotoxicity biomarker AChE were measured in $C$. ponticus after exposure to $50 \%, 5 \%, 0.5 \%$, and $0.05 \%$ of $\operatorname{LC}_{50}(48 \mathrm{~h})$ (Fig. 3). The activity of all enzymes analyzed was significantly $(p<0.05)$ impacted by time exposure and NiO NPs concentrations (Table 1). In addition, a significant interactive effect was observed for exposure time and NiO NPs concentration $(p<0.05)$ (Table 1).

\section{SOD activity}

The level of SOD activity in C. ponticus after NiO NP exposure showed significant stimulation $(p<0.05)$ with increasing exposure time and NiO NP concentrations (Fig. 3a). The maximum SOD activity was $31 \pm 0.7 \mathrm{U} / \mathrm{mg}$ protein and was observed for the highest NiO NPs concentration (2 mg/L) after $48 \mathrm{~h}$. For the control groups, SOD activity was $4.0 \pm 0.3 \mathrm{U} / \mathrm{mg}$ protein.

\section{CAT activity}

After $24 \mathrm{~h}$ of incubation, a significant $(p<0.05)$ difference was observed between the control groups and copepods exposed to NiO NPs concentrations (Fig. 3b). The level of CAT activity was $71.3 \pm 2.5 \mathrm{U} / \mathrm{mg}$ protein at the highest concentration $(2 \mathrm{mg} / \mathrm{L})$, compared with $31.4 \pm 0.8 \mathrm{U} / \mathrm{mg}$ protein in control groups. After $48 \mathrm{~h}$, CAT activity decreased significantly $(p<0.05)$ at $0.2 \mathrm{mg} / \mathrm{L}(19.2 \pm 1.7 \mathrm{U} / \mathrm{mg}$ protein $)$ and $2 \mathrm{mg} / \mathrm{L}$ (12.8 $\pm 3.0 \mathrm{U} / \mathrm{mg}$ protein) compared with the control groups $(32.3 \pm 2.5 \mathrm{U} / \mathrm{mg}$ protein).

\section{GST activity}

After $24 \mathrm{~h}$, exposure to NiO NPs led to a significant $(p<0.05)$ increase in GST activity in a dose-dependent manner (Fig. 3c). At $2 \mathrm{mg} / \mathrm{L}$, GST activity reached $65.8 \pm 5.2$ $\mathrm{nmol} / \mathrm{min} / \mathrm{mg}$ protein, in comparison with $20.4 \pm 1.7 \mathrm{nmol} / \mathrm{min} / \mathrm{mg}$ protein for the control groups. A significantly $(p<0.05)$ higher level of GST activity was also observed after $48 \mathrm{~h}$ relative to the values measured after $24 \mathrm{~h}$ of incubation.

\section{Acetylcholinesterase activity}

Exposure to NiO NPs for $24 \mathrm{~h}$ resulted in significant $(p<0.05)$ stimulation of AChE activity at all concentrations, with a minimum activity level of $67.4 \pm 4.4 \mathrm{nmol} / \mathrm{min} / \mathrm{mg}$ 
protein at $0.002 \mathrm{mg} / \mathrm{L}$ and a maximum of $296.4 \pm 6.4 \mathrm{nmol} / \mathrm{min} / \mathrm{mg}$ protein at $2 \mathrm{mg} / \mathrm{L}$ (Fig. 3d). After $48 \mathrm{~h}$ at NiO NPs concentrations ranging from 0.002 to $0.2 \mathrm{mg} / \mathrm{L}$, AChE activity was higher than the levels observed after $24 \mathrm{~h}$. However, at the highest $\mathrm{NiO}$ NPs concentration tested (2 mg/L), AChE activity was significantly reduced (34.1 $\pm 3.3 \mathrm{nmol} / \mathrm{min} / \mathrm{mg}$ protein) in comparison with the control group (52.37.3 \pm 2.7 $\mathrm{nmol} / \mathrm{min} / \mathrm{mg}$ protein $)(p<0.05)$.

\section{Discussion}

\section{Acute toxicity test and aggregation behavior of NiO NPs}

The results demonstrated the lethal acute toxicity of NiO NPs on adult copepod $C$. ponticus under short-term exposure (up to $48 \mathrm{~h}$ ), with an $\mathrm{LC}_{50}$ value of $13.83 \mathrm{mg} / \mathrm{L}$ and $4.07 \mathrm{mg} / \mathrm{L}$ for 24 and $48 \mathrm{~h}$, respectively. To our knowledge, this is the first study to report on the lethal effect NiO NPs on marine planktonic copepods. Available data regarding the lethal effect of NiO NPs on marine organisms in general are scarce and the majority of previous research has focused on freshwater species (Table 3). To our knowledge, only one previous study has investigated the mortality effect of NiO NPs on the marine amphipod Leptocheirus plumulosus (Hanna et al. 2013). The results from this study indicated that NiO NPs, tested at concentrations from 500 to 2000 $\mu \mathrm{g} / \mathrm{g}$ dry weight, provoked no mortality in the amphipod over 10 days (Hanna et al. 2013).

In freshwater crustacean species including Daphnia magna, Gong et al. (2016) observed a nine-fold higher value of $\operatorname{LC}_{50}(48 \mathrm{~h})(36.79 \mathrm{mg} / \mathrm{L}$ for neonates) than found here for C. ponticus (Table 3). However, similar values of $\mathrm{LC}_{50}(24 \mathrm{~h})$ as the $48 \mathrm{~h}$ $\mathrm{LC}_{50}$ found in the present study for $C$. ponticus were reported by Nogueira et al. (2015) for the same life stage of D. magna exposed to NiO NPs (Table 3). Very high $\mathrm{LC}_{50}$ values for $\mathrm{NiO} \mathrm{NPs}$ have been recorded in other biological models at higher trophic levels, such as in adult zebrafish under acute $\left(\mathrm{LC}_{50}(48 \mathrm{~h})=760 \mathrm{mg} / \mathrm{L}\right)$ and chronic exposure $\left(\operatorname{LC}_{50}(30\right.$ days $\left.)=45 \mathrm{mg} / \mathrm{L}\right)$ (Kovrižnych et al. 2013, 2014). Other studies on the toxic effects of NiO NPs have shown that exposure of the freshwater alga Chlorella vulgaris to a concentration of $13.7 \mathrm{mg} / \mathrm{L}$, i.e., close to our $\mathrm{LC}_{50}(24 \mathrm{~h})$, reduces the viability of exposed cells to $50 \%$ after $72 \mathrm{~h}$ (Oukarroum et al. 2017). Kanold et al. (2016) did not observe mortality effects of nickel nanoparticles (Ni NPs) 
381

382

383

384

385

386

387

388

389

390

391

392

393

394

395

396

397

398

399

400

401

402

403

404

405

406

407

408

409

410

411

412

413

on the early life stage of the sea urchin Paracentrotus lividus exposed to concentrations up to $3 \mathrm{mg} / \mathrm{L}$ of Ni NPs after $48 \mathrm{~h}$, which correspond to $88 \mu \mathrm{g} / \mathrm{L}$ of $\mathrm{Ni}^{2+}$.

In this study, NiO NPs displayed aggregation in seawater during the acute lethal and sublethal tests at concentrations ranging from 2 to $50 \mathrm{mg} / \mathrm{L}$, after $48 \mathrm{~h}$. This in line with findings observed by Sousa et al. (2018b) and Zhou et al. (2016), who observed similar behavior for NiO NPs and Ni NPs at concentrations ranging from 4 to 10 $\mathrm{mg} / \mathrm{L}$ after $72 \mathrm{~h}$. Like other nanoparticles (titanium oxide (TiO2) NPs, silver (Ag) NPs), NiO NPs tend to aggregate independently of the aqueous medium (freshwater, seawater, deionized water, etc.), forming larger aggregates in seawater than in freshwater due to seawater characteristics favoring aggregation (Ates et al. 2016). The agglomerates increased in size with time varying from few hundred nanometers to several microns both in seawater or freshwater (Wang et al. 2014; Ates et al. 2016; Sousa et al. 2018a). Additionally, NiO NP aggregation does not exclude the possibility of release of free dissolved Nickel ions $\left(\mathrm{Ni}^{2+}\right)$ in the aqueous medium test, which may also impact the physiology of the copepod (Gong et al. 2011; Sousa et al. 2018b). Unfortunately, NiO NPs dissolution behavior was not examined here to get a clear idea of the amount of dissolved $\mathrm{Ni}^{2+}$ released into seawater test medium that can act in NiO NPS toxicity. Previous studies indicated a low solubility of these NPs in an aqueous medium test which is higher in freshwater (7\%) than in seawater $(0.14 \%)$ under short-term periods (Ates et al. 2016; Oukarroum et al. 2017; Gong et al. 2011, 2019). The availability of $\mathrm{Ni}^{2+}$ released into the seawater from NPs increased with time and NiO NPs concentrations (Hanna et al. 2013; Zhou et al. 2016; Oukarroum et al. 2017; Gong et al. 2011, 2019). Hanna et al. (2013) reported a slow dissolution of NiO NPs under a long-term period, where NPs dissolved over several weeks in seawater. The same authors reported a solubility of $21 \%$ of NiO NPs after 28 days for a concentration of $10 \mathrm{mg} / \mathrm{L}$ of NiO NPs which is higher than solubility observed in others studies under short-term test (Gong et al. 2011, 2019). For $50 \mathrm{mg} / \mathrm{L}$ of NiO NPs, a concentration which causes $100 \%$ lethality in copepods after $48 \mathrm{~h}$, a previous study has reported a concentration of $110 \mu \mathrm{g} / \mathrm{L}$ of $\mathrm{Ni}^{2+}$ released in seawater after $96 \mathrm{~h}$ (Gong et al. 2011). Copepods are therefore exposed to both particle and dissolved forms of NiO NPs and toxicity can be linked to $\mathrm{Ni}^{2+}$ released ion from NPs (Sousa et al. 2018b), to the particles themselves (Capasso et al. 2014) or to the combined effect 
414 of $\mathrm{Ni}^{2+}$ and NPs aggregates (Gong et al. 2011, 2019). Further work needs to be done 415 to better explain the chemical mechanism involved in NiO NPs copepods toxicity effects and to determine the real NiO NPs concentrations.

417 Settling of NiO NPs, as observed on the exoskeleton of $C$. ponticus in this study, has also been observed for Chlorella vulgaris and the brine shrimp Artemia salina (Gong et al. 2011; Ates et al. 2016). Biological surface coating by NPs, is considered as the main mechanism of toxicity for no-ion releasing NPs or low soluble NPs such as NiO NPs, deemed to alter the swimming behavior of aquatic organisms which could lead to negative impacts in aquatic ecosystems (Gong et al. 2011; Noss et al. 2013; Oukarroum et al. 2017; Gong et al. 2019).

According to Sukhanova et al. (2018), the lethal toxicity effect of NiO NPs on aquatic organisms depends on the biological model (size, life stage, weight) and on nanoparticle characteristics (size, shape, behavior). To our knowledge, the $\mathrm{LC}_{50}(48 \mathrm{~h}$ ) observed in the present study is lower than any $\mathrm{LC}_{50}$ value reported previously in the literature, which suggests that copepods can be a good bio-indicator of the toxic effects of NiO NPs. Comparison of our $\mathrm{LC}_{50}$ values with NiO NPs environmental concentrations is not possible due to the lack of data in aquatic environments. However, it is worth noting that mortality effect of NiO NPs on of C. ponticus was observed at concentrations that were much higher than predicted environmental concentrations, which do not exceed the $\mu \mathrm{g}$ range (Zhang et al. 2019). Thus, the concentrations reported in this study may reflect the lethal effect upon accidental exposure to NiO NPs.

\section{Effect on reproductive traits}

Our results showed that NiO NPs did not impact the reproductive performance (EPR and HS) of $C$. ponticus at a concentration of $0.002 \mathrm{mg} / \mathrm{L}$ during $48 \mathrm{~h}$ of exposure. However, EPR and HS were significantly affected at NiO NP concentrations $\geq 0.02$ $\mathrm{mg} / \mathrm{L}$. Previous studies have also found that metallic nanoparticles (e.g., zinc oxide (ZnO) NPs and Ni NPs) are associated with impairment of copepod reproductive traits (Zhou et al. 2016; Parlapiano et al. 2017). Time exposure and concentration had a strong influence on EPR (Table 1), which decreased with increasing NiO NPs concentration and time exposure (by $32 \%$ and $46 \%$, respectively, at $0.02 \mathrm{mg} / \mathrm{L}$ and by $70 \%$ and $82 \%$, respectively, at $2 \mathrm{mg} / \mathrm{L}$ after $24 \mathrm{~h}$ and $48 \mathrm{~h}$ ). Similar effects have been 
observed in the crustacean species D. magna, with NiO NPs markedly reducing offspring production at concentrations $\geq 0.2 \mathrm{mg} / \mathrm{L}$ after 21 days (Gong et al. 2016). Despite the difference in incubation duration and probably frequent renewal of test solution in that study, reproduction success in C. ponticus was impacted at much lower concentrations $(\geq 0.02 \mathrm{mg} / \mathrm{L})$ than those tested by Gong et al. (2016). Likewise, Zhou et al. (2016) did not observe any effect on EPR in the marine calanoid copepod Acartia tonsa at Ni NPs concentrations up to $0.01 \mathrm{mg} / \mathrm{L}$ over 4 days.

The results in the present study showed significant concentration-related trends in HS, which decreased with increasing NiO NPs concentrations. At the highest concentration tested here ( $2 \mathrm{mg} / \mathrm{L})$, HS was reduced by $70 \%$ and $79 \%$, respectively, for eggs produced after $24 \mathrm{~h}$ and $48 \mathrm{~h}$. Zhou et al. (2016) also observed a negative effect of Ni NPs on HS of the copepod A. tonsa at a concentration of $17 \mathrm{mg} / \mathrm{L}$, where only $9 \%$ of incubated eggs hatched. Similar responses to NiO NPs have been observed in zebrafish, including a delay in egg hatching and a reduction in HS at concentrations ranging from 100 to $800 \mathrm{mg} / \mathrm{L}$ (Kovrižnych et al. 2013). Our results provide evidence of the impact of NiO NPs on copepod reproductive success at much lower concentrations $(0.02 \mathrm{mg} / \mathrm{L})$ than those tested in previous studies on marine organisms. To our knowledge, only one study has reported similar negative effects, on reproduction of the freshwater crustacean D. magna, at similar NiO NPs concentrations $(0.045-0.14 \mathrm{mg} / \mathrm{L})$ to those tested in the present study (Nogueira et al. 2015). Regarding NiO NPs solubility at the sublethal concentrations tested here (0.002-2 $\mathrm{mg} / \mathrm{l})$ and according to our knowledge, there are no data in the literature on $\mathrm{NiO}$ NPs solubility in seawater at the same concentrations range. The study of Sousa et al. (2018b) reported a concentration of $\mathrm{Ni}^{2+}$ of $250 \mu \mathrm{g} / \mathrm{L}$ released in deionized water after $72 \mathrm{~h}$ from a concentration of $1.6 \mathrm{mg} / \mathrm{L}$. Based on this finding and considering the low solubility of NiO NPs in seawater in comparison to freshwater, we can suggest that the concentration of $\mathrm{Ni}^{2+}$ released in seawater at concentration of $2 \mathrm{mg} / \mathrm{L}$, under our experimental conditions, could be less or close to $250 \mu \mathrm{g} / \mathrm{L}$. This concentration is well higher than the highest levels of nickel which are not expected to pose a significant risk in species in saltwater under acute $(74 \mu \mathrm{g} / \mathrm{L})$ and chronic $(8.3 \mu \mathrm{g} / \mathrm{L})$ exposure as fixed by US EPA Aquatic Life Criteria Water Quality Standards (EPA 2009). 
Interestingly, the NiO NPs concentrations causing toxic effects on reproduction physiology in C. ponticus and D. magna are close to those measured in contaminated ecosystems, which are suspected to occur at $\mu \mathrm{g}$ range, suggesting that environmentally realistic concentrations of NiO NPs are likely to impact reproduction of both species. Reproduction is a crucial biological function in organisms to maintain existence of species. Impairment of reproduction in copepods by NiO NPs, as observed in this study, can result in alteration of marine community structure and in modification of the food trophic web.

\section{Oxidative stress}

In order to understand the mechanisms of NiO NPs toxicity at cellular level, changes in the activity of antioxidant enzymes and a neurotoxicity biomarker in C. ponticus under short-term NiO NPs exposure were investigated. The results indicated a significant modulation of the first-defense antioxidant enzymes SOD and CAT in $C$. ponticus in response to sublethal exposure to NiO NPs. The stimulation of antioxidant enzymes was possibly a defense mechanism for coping with the oxidative stress generated by NiO NPs. This is in line with previous studies showing ability of nanoparticles to generate oxidative stress in aquatic organisms under short-term exposure (e.g. the brine shrimp Artemia salina, the copepod Calanus finmarchirus, the fish Nile tilapia, etc.) (Abdel-khaled et al. 2015; Ates et al. 2016; Farkas et al. 2020).

Our results showed that antioxidant enzyme levels in $C$. ponticus were significantly influenced by time exposure and NiO NPs concentration. Expression of SOD and CAT enzymes exhibited similar patterns, with an increasing trend after $24 \mathrm{~h}$ that was probably linked to production of reactive oxygen species (ROS), namely $\mathrm{O}_{2}$ and $\mathrm{H}_{2} \mathrm{O}_{2}$, in $C$. ponticus as a consequence of $\mathrm{NiO}$ NPs exposure, as previously observed in various freshwater microalgae and plants (e.g., Chlorella vulgaris, Pseudokirchneriella subcapitata, Lemna gibba) (Oukarroum et al. 2015; Oukarroum et al. 2017; Sousa et al. 2018b; Gong et al. 2019). After 48 h, SOD activity showed a similar trend as at $24 \mathrm{~h}$, while there was a significant reduction in CAT enzymatic activity at the two highest concentrations of NiO NPs $(0.2$ and $2 \mathrm{mg} / \mathrm{L})$. This decrease might be linked to high production of $\mathrm{H}_{2} \mathrm{O}_{2}$ by SOD and limited capacity of CAT to degrade it (Ighodaro and Akinloye 2018). Such antioxidant stress response was also 
reported in the marine copepods Tigriopus japonicus exposed to sunscreens containing Zinc oxide nanoparticle (ZnO NPs); with high ROS levels observed after $96 \mathrm{~h}$ at environmentally realistic concentrations of ZnO NPs (Wong et al. 2020).

In combination with the antioxidant response, exposure to NiO NPs also induced activation of the multifunctional GST enzyme over the whole exposure period (48 h). In line with our results, Farkas et al. (2020) reported that exposure to silver nanoparticles (Ag NPs) triggered an increase in gene expressions of antioxidant enzymes GST in the copepod Calanus finmarchirus after 96 h. GST enzyme plays a key role in biotransformation of endogenous and exogenous toxic compounds present in the cell and is also recognized as an indicator of lipid damage (Prione et al. 2016; Dasari et al. 2017). NiO NPs has previously been reported as inductor of lipids peroxidation at concentrations of 1 to $50 \mathrm{mg} / \mathrm{L}$ in Artemia salina and Gracilaria lemaneiformis (Han et al. 2012; Ates et al. 2016). Results of the present study are in accordance with the results observed for the copepod Eucyclop sp. exposed to titanium dioxide nanoparticle $\left(\mathrm{TiO}_{2}\right)$ combined to lead $(\mathrm{Pb})$, where Glutathione peroxidase (GPx), Glutathione reductase (GR), and CAT significantly increased after contaminant accumulation confirming that the exposed copepods had suffered from oxidative stress triggered by $\mathrm{TiO}_{2}$ and $\mathrm{Pb}$ (Matouke and Mustapha, 2018).

Neurotoxicity is one manifestation of oxidative stress damage induced by chemicals. The enzyme AChE hydrolyzes the neurotransmitter acetylcholine (Ach) to acetate and choline, in order to prevent constant stimulation of the synapse. The present study showed a stimulating effect on AChE activity of NiO NPs (0.002-2 mg/L) after $24 \mathrm{~h}$, but we observed a significant reduction in AChE activity at $2 \mathrm{mg} / \mathrm{L}$ of NiO NPs after 48 h. Under metals exposure, AChE exhibited the same pattern in living organisms, depending on time exposure; AChE increased during the earliest hours of metal exposure and then decreased with time (Bainy et al. 2006; Emadeldeen 2014; Ensibi and Yahia, 2017).

The high level of AChE activity in C. ponticus observed in this study may be related to interactions between NiO NPs and acetylcholine receptors causing accumulation of free unbound acetylcholine at cholinergic receptor sites. Some authors considered the excess production of AChE activity as a compensatory mechanism related to an initial reduction in this enzyme by pollutants (Bainy et al. 2006; Ferreira et al. 2012). 
Inhibition of AChE activity is commonly used as an indicator of neurotoxicity in

543 living organisms such as copepods and cladoceran species under exposure to metal and pesticide (Forget et al. 2003; Cailleaud et al. 2007; Ensibi et Yahia. 2017). Inactivation of AChE activity at a concentration of $2 \mathrm{mg} / \mathrm{L}$ suggests that $\mathrm{NiO} \mathrm{NPs}$ can affect the brain of aquatic species and cause neurotoxicity through disturbance of cholinergic neurotransmission. Similar inhibitory effects of metal nanoparticles (silicon dioxide $\left(\mathrm{SiO}_{2}\right), \mathrm{TiO}_{2}$, aluminum oxide $\left(\mathrm{Al}_{2} \mathrm{O}_{3}\right)$, and aluminum (Al) NPs) on AChE have been observed previously and are reported to depend on nanoparticle concentration (Wang et al. 2009). This reduction can be explained by the excess production of AChE in $C$. ponticus ceased at a NiO NPs concentration of $2 \mathrm{mg} / \mathrm{L}$. Previous research has suggested, not confirmed, that modulation of AChE enzyme in copepods can result in a disorder in swimming behavior, tetany, and paralysis (Forget et al. 2003; Ferreira et al. 2012). Swimming behavior response of aquatic organisms, such as fish and cladocerans (Daphnia sp.), under contaminant exposure, has been reported to be strongly related to AChE activity. Further, it increases as the levels of AChE enzyme increase while the opposite occurs when AChE enzyme levels decrease, impacting, therefore, the survival of living organisms (Bonansea et al. 2016; Ren and al. 2017). Therefore, alteration of swimming movement in copepods may have severe impacts in the copepods community which affect other communities of the ecosystem because it is associated with numerous vital functions like perception and acquisition of food, mating and reproduction, predator-prey interaction, respiration rate, and social behavior as stated by Mazzocchi and Paffenhofer (1999).

Changes in these biomarkers reflected the ability of NiO NPs to trigger oxidative stress and highlighted the significant contribution of time exposure and NiO NPs concentration in the response of $C$. ponticus to oxidative stress. Our results provide evidence that oxidative stress is one of the main mechanisms of nanoparticle toxicity in copepods under short-term exposure, as previously reported for other species (Sousa et al. 2018b; Gong et al. 2019). 


\section{Conclusions}

575 This is the first study to examine the potential toxic effects of NiO NPs on a marine 576 planktonic calanoid copepod. $\mathrm{A} \mathrm{LC}_{50}(48 \mathrm{~h})$ of around $4 \mathrm{mg} / \mathrm{L}$ was found for adult 577 females of $C$. ponticus, a concentration that can exceed the environmental 578 concentrations in contaminated environments. Results from sublethal tests clearly 579 indicated that $\mathrm{NiO}$ NPs caused negative effects on reproductive performance in $C$. 580 ponticus and led to oxidative stress at concentrations $(0.02-2 \mathrm{mg} / \mathrm{L})$, which are close 581 to environmentally relevant levels. C. ponticus resisted to the oxidative stress 582 generated by NiO NPs by increasing the levels of antioxidant enzymes in a 583 concentration and time-dependent manner. These results provide a better 584 understanding of the ecotoxicological risks of NiO NPs for marine organisms and 585 confirm that the calanoid copepod C. ponticus is a suitable marine model organism for 586 ecotoxicology studies. Future studies are required to determine the effects of NiO NPs 587 on the entire copepod life cycle, including impacts on juvenile development and 588 growth, and under long-term exposure. 


\section{Acknowledgements}

592 The authors would like to thank the members of the Laboratory for Environmental

593 Biomonitoring (Faculty of Sciences of Bizerte; Tunisia), especially Professor

594 Mohamed Dalleli and Ms Wiem Saidani, for their help in biomarker analysis. We are 595 also grateful to the Institute of Fishing and Aquaculture (ISPA) (Bizerte, Tunisia), 596 especially Professor Mohammed Chalghaf, for algae supply. Special thanks to 597 Professor Abdelhak Othmani for providing nanoparticles. We would like to thank 598 Mary McAfee for the English correction and improvement.

599 This research is part of the PhD work of Ms Emna Djebbi, which is co-funded by the 600 University of Carthage (Bourse d'Alternance) and IRD-Tunisia (Institut de Recherche 601 pour le Développement). 


\section{References}

Abdel-Khalek AA, Kadry M, Hamed A, Marie MA (2015) Ecotoxicological impacts of zinc metal in comparison to its nanoparticles in Nile tilapia; Oreochromis niloticus. J Basic Appl Zool 72:113-125. https://doi.org/10.1016/j.jobaz.2015.08.003.

Ada K, Turk M, Oguztuzun S, Kilic M, Demirel M, Tandogan N, Ersayar E, Latif O (2010) Cytotoxicity and apoptotic effects of nickel oxide nanoparticles in cultured HeLa cells. Folia Histochem Cytobiol 48:524-529. https://doi.org/10.2478/v10042-010-0045-8. Ates M, Demir V, Arslan Z, Camas M, Celik F (2016) Toxicity of engineered nickel oxide and cobalt oxide nanoparticles to Artemia salina in seawater. Water Air Soil Pollut 227:70. https://doi.org/10.1007/s11270-016-2771$\underline{9}$

Avila-Arias H, Loring F. Nies LF, Gray MB, Turco RF (2019) Impacts of molybdenum, nickel, and lithium oxide nanomaterials on soil activity and microbial community structure. Sci Total Environ 652: 202-211. https://doi.org/10.1016/j.scitotenv.2018.10.189.

Bainy ACD, Medeiros MHG, Di Mascio P, de Almeida EA (2006) In vivo effects of metals on the acetylcholinesterase activity of the Perna perna mussel's digestive gland. Biotemas 19:35-39. https://doi.org/10.5007/\%X.

Bradford MM (1976) A rapid and sensitive method for the quantitation of microgram quantities of Protein utilizing the principle of protein-dye binding. Anal Biochem 72:248-254. https://doi.org/10.1016/0003-2697(76)90527-3.

Bianchi F, Acri F, Bernardi Aubry F, Berton A, Boldrin A, Camatti E, Cassin D, Comaschi A (2003) Can plankton communities be considered as bio-indicators of water quality in the Lagoon of Venice? Mar Bull Poll 46:964-971. https://doi.org/10.1016/S0025-326X(03)00111-5.

Bonansea RI, Wunderlin DA, Amé MV (2016) Behavioral swimming effects and acetylcholinesterase activity changes in Jenynsia multidentata exposed to chlorpyrifos and cypermethrin individually and in mixtures. Ecotox and Environ Safe 129:311-319. https://doi.org/10.1016/j.ecoenv.2016.03.043.

Cailleaud K, Maillet G, Budzinski H, Souissi S, Forget JL (2007) Effects of salinity and temperature on the expression of enzymatic biomarkers in Eurytemora affinis (Calanoida, Copepoda). Comp Biochem Phys A 174:841-849. https://doi.org/10.1016/j.cbpa.2006.09.012.

Cailleaud K, Budzinski H, Lardy S, Augagneur S, Barka S, Souissi S, Forget-Leray J (2011) Uptake and elimination, and effect of estrogen-like contaminants in estuarine copepods: An experimental study. Environ Sci Pollut R 18:226-236. https://doi.org/10.1007/s11356-010-0355-6.

Capasso L, Camatini M, Gualtieri M (2014) Nickel oxide nanoparticles induce inflammation and genotoxic effect in lung epithelial cells. Toxicol Lett 226: 28-34. https://doi.org/10.1016/j.toxlet.2014.01.040.

Claiborne A (1985) Catalase activity. In: Greenwald RA (ed) Handbook of methods for oxygen Radical research. CRC Press, Boca Raton, Florida, pp 283-284.

Dasari S, Ganjayi MS, Oruganti L, Balaji H, Meriga B (2017) Glutathione s-transferases detoxify endogenous and exogenous toxic agents-mini review. J Dairy Vet Anim Res 5:157-159. https://doi.org/10.15406/jdvar.2017.05.00154.

Ellman GL, Courtney KD, Andres VJR, Feather-Stone RM (1961) A new and rapid colorimetric determination of acetylcholinesterase activity. Biochem Pharmacol 7:88-90. https://doi.org/10.1016/0006-2952(61)90145-9. 
Emadeldeen HM (2014) Biochemical response of the cyclopoida copepod Apocyclops borneoensis exposed to nickel. Jordan J Biol Sci 7:41-47. https://doi.org/10.12816/0008212.

Ensibi C, Pringault O, Hasnnaoui W, Yahia MND (2015) Effects of cadmium exposure on reproduction and survival of the planktonic copepod Centropages ponticus. J Marine Sci Res Dev 5:159. https://doi.org/10.4172/2155-9910.100015 9

Ensibi C, Yahia MND (2017) Toxicity assessment of cadmium chloride on planktonic copepods

650 Centropages ponticus using biochemical markers. Toxicol Rep 4:83-88.

651 https://doi.org/10.1016/j.toxrep.2017.01.005.

EPA U (2009) National recommended water quality criteria. United States Environmental Protection Agency, Office of Water, Office of Science and Technology.

Farkas J, Cappadona V, Olsen AJ, Hansen BH, Posch W, Ciesielski TM, Goodhead R, Wilflingseder D, Blatzer M, Altin D, Moger J, Booth AM, Jenssen BM (2020) Combined effects of exposure to engineered silver nanoparticles and the water-soluble fraction of crude oil in the marine copepod

657 Calanus finmarchicus. Aquatic

659 Ferreira G, Carvalho-Silva M, Gonçalves C, Silva J, Scaini G, Ghedim F, Deroza P, Zugno A, Pereira 660 T, Oliveira G, Kist L, Bogo M, Schuck P, Ferreira G, Streck E (2012) L-Tyrosine administration increases acetylcholinesterase activity in rats. Neurochem Int 61:1370-1374. https://doi.org/10.1016/j.neuint.2012.09.017.

Fossi MC, Minutoli R, Guglielmo L (2001) Preliminary results of biomarker responses in zooplankton of brackish environments. Mar Pollut Bull 42:745-748. https://doi.org/10.1016/S0025-326X(00)00214$\underline{9}$.

Fossi MC, Urban J, Maltese S, Mazzi L, Coppola D, Casini S, Panigada S, Lauriano G, Niño C, RojasBracho L, Marsili L (2010) First assessment of biomarker responses and contaminant levels in Balaenoptera Edeni skin biopsies of gulf of California (Mexico). J Plankton Res 32:1227-1229.

Forget LJ, Beliaeff B, Bocquené G (2003) Acetylcholinesterase activity in copepods (Tigriopus brevicornis) from the Vilaine River estuary, France, as a biomarker of neurotoxic contaminants. Aquat 671 Toxicol 62:195-204. https://doi.org/10.1016/S0166-445X(02)00084-X.

672 Geissen V, Mol H, Klumpp E, Umlauf G, Nadal M, Ploeg MVD, Van de Zeea SEATM, Ritsema CJ (2015) Emerging pollutants in the environment: A challenge for water resource management. Int Soil Water Conserv Res 3:57-65 http://dx.doi.org/10.1016/jiswcr.2015.03.002.

Gomes SLL, Carlos P.Roca CP, Scott-Fordsmand JJ, Amorim MJ (2019) High-throughput transcriptomics: Insights into the pathways involved in (nano) nickel toxicity in a key invertebrate test species. Environ Pollut 245: 131-140. https://doi.org/10.1016/j.envpol.2018.10.123Get.

Gong N, Shao K, Feng W, Lin Z, Liang C, Sun Y (2011) Biotoxicity of nickel oxide nanoparticles and bio-remediation by microalgae Chlorella vulgaris. Chemosphere 83:510-516. https://doi.org/10.1016/j.chemosphere.2010.12.059.

681 Gong N, Shao K, Li G, Sun Y (2016) Acute and chronic toxicity of nickel oxide nanoparticles to Daphnia magna: The influence of algal enrichment. NanoImpact 3-4:104-109. http://dx.doi.org/10.1016/j.impact.2016.08.003.

684 Gong N, Shao K, Che C, Sun Y (2019) Stability of nickel oxide nanoparticles and its influence on 685 toxicity to marine algae Chlorella vulgaris. Mar Pollut Bull 149: 110532. 686 https://doi.org/10.1016/j.marpolbul.2019.110532. 
Habig WH, Pabst MJ, Jakoby WB (1974) Glutathione S-transferases. The first enzymatic step in mercapturic acid formation. J Biol Chem 249:7130-7139.

Han ZX, Zhang M, Lv CX (2012) Bioaccumulation and toxicity of $\mathrm{NiO}$ nanoparticles in Gracilaria lemaneiformis. Advanced Mater Res 518-523: 942-945. https://doi.org/10.4028/www.scientific.net/AMR.518-523.942.

Hanna SK, Miller RJ, Zhou D, Keller AA, Lenihan HS (2013) Accumulation and toxicity of metal oxide nanoparticles in a soft-sediment estuarine amphipod. Aquat Toxicol 142-143: 441-446. https://doi.org/10.1016/j.aquatox.2013.09.019.

Hussain MB, Laabir M, Daly Yahia MN (2020) A novel index based on planktonic copepod reproductive traits as a tool for marine ecotoxicology studies. Sci Total Environ 727:138621. https://doi.org/10.1016/j.scitotenv.2020.138621.

Ighodaro OM, Akinloye OA (2018) First line defence antioxidants-superoxide dismutase (SOD), catalase (CAT) and glutathione peroxidase (GPX): Their fundamental role in the entire antioxidant defence grid. Alexandria J Med 54:287-293. https://doi.org/10.1016/j.ajme.2017.09.001.

ISO 14669 (1999 revised 2015) Water quality determination of acute lethal toxicity to marine copepod (Copepoda, Crustacea). International Organization for Standardisation, Switzerland.

Jayalakshmi T, Santhanam P (2019) A microcosm study on the impact of acidification on feeding, survival, nauplii production rate, post-embryonic development and nutritional composition of marine copepod. In : Santhanam P, Begum A, Pachiappan P (eds) Basic and Applied Zooplankton Biology. Springer, Singapore, 395-428. https://doi.org/10.1007/978-981-10-7953-5_18.

Kanold JM, Wang J, Brümmer F, Siller L (2016) Metallic nickel nanoparticles and their effect on the embryonic development of the sea urchin Paracentrotus lividus. Environ Pollut 212: 224-229. https://doi.org/10.1016/j.envpol.2016.01.050.

Khan I, Saeed K, Khan I (2019) Nanoparticles: properties, applications and toxicities. Arab J Chem 12:908-931. https://doi.org/10.1016/j.arabjc.2017.05.011

Kim BM, Rhee JS, Jeong CB, Seo JS, Park GS, Lee YM, Lee JS (2014) Heavy metals induce oxidative stress and trigger oxidative stress-mediated heat shock protein (hsp) modulation in the intertidal copepod Tigriopus japonicus. Comp Biochem Physiol C Toxicol Pharmacol 166:65-74. https://doi.org/10.1016/j.cbpc.2014.07.005.

Kovrižnych JA, Sotníková R, Zeljenková D, Rollerová E, Szabová E, Wimmerová S (2013) Acute toxicity of 31 different nanoparticles to zebrafish (Danio rerio) tested in adulthood and in early life stages - comparative study. Interdiscip Toxicol 6:67-73. https://doi.org/10.2478/intox-2013-0012.

Kovrižnych AJ, Sotníková R, Zeljenková D, Rollerová E, Szabová E (2014) Long-term (30 days) toxicity of $\mathrm{NiO}$ nanoparticles for adult zebrafish Danio rerio. Interdiscip Toxicol 7:23-26. https://doi.org/10.2478/intox-2014-0004.

Lauer MM, Bianchini A (2010) Chronic copper toxicity in the estuarine copepod Acartia tonsa at different salinities. Environ Toxicol Chem 29:2297-303. https://doi.org/10.1002/etc.285.

Mahmoud AM, Ibrahim FA, Shaban SA, Youssef NA (2015) Adsorption of heavy metal ion from aqueous solution by nickel oxide nano catalyst prepared by different methods. Egypt J Pet 24:27-35. https://doi.org/10.1016/j.ejpe.2015.02.003.

Manke A, Wang L, Rojanasakul Y (2013) Mechanisms of nanoparticle-induced oxidative stress and toxicity. Biomed Res Int 1:942916. http://dx.doi.org/10.1155/2013/942916. 

(Eucyclop sp.) fed Chlorella ellipsoides exposed to titanium dioxide $\left(\mathrm{TiO}_{2}\right)$ nanoparticles and lead $(\mathrm{Pb}$ 2+). Aquat Toxicol 198: 30-39. https://doi.org/10.1016/j.aquatox.2018.02.013.

Mazzocchi MG, Paffenhöfer GA (1999) Swimming and feeding behavior of the planktonic copepod Clausocalanus furcatus. J Plankton Res 21:1501-1518. https://doi.org/10.1093/plankt/21.8.1501.

McCord JM, Fridovich I (1969) Superoxide dismutase: an enzymic function for erythrocuprein (hemocuprein). J Biol Chem 244:6049-6055.

Miglietta ML, Rametta G, Di Francia G, Manzo S, Rocco A, Carotenuto R, De Luca Picione F, Buono $S$ (2015) Characterization of nanoparticles in seawater for toxicity assessment towards aquatic organisms. Lect Notes Electr Eng, 91: 425-429. https://doi.org/10.1007/978-94-007-1324-6_69.

Nogueira V, Lopes I, Rocha-Santos TAP, Rasteiro MG, Abrantes N, Gonçalves F, Soares AMVM, Duarte AC, Pereira R (2015) Assessing the ecotoxicity of metal nano-oxides with potential for wastewater treatment. Environ Sci Pollut R 22:13212-13224. https://doi.org/10.1007/s11356-015$\underline{4581-9}$.

Noss C, Dabrunz A, Rosenfeldt RR, Lorke A, Schulz R (2013) Three-dimensional analysis of the swimming behavior of Daphnia magna exposed to nanosized titanium dioxide.18: PLoS One 8: e80960. https://doi.org/10.1371/journal.pone.0080960.

Oukarroum A, Barhoumi L, Samadani M, Dewez D (2015) Toxic effects of nickel oxide bulk and nanoparticles on the aquatic plant Lemna gibba L. Biomed Res Int 2015:1-7. http://dx.doi.org/10.1155/2015/501326.

Oukarroum A, Zaidi W, Samadani M, Dewez D (2017) Toxicity of nickel oxide nanoparticles on a freshwater green algal strain of Chlorella vulgaris. Biomed Res Int 2017:1-8 https://doi.org/10.1155/2017/9528180.

Parlapiano I, Biandolino F, Russo V, Manfra L, Rotini A, Migliore L, Prato E (2017) Chronic toxicity of $\mathrm{ZnO}$ nanoparticles: effects on survival and reproductive traits of the marine copepod Tigriopus fulvus. PeerJ preprints 5:e3276v1. https://doi.org/10.7287/peerj.preprints.3276v1.

Pinho GLL, Mora da Rosa A, Macial EF, Bianchini A, Yunes JS, Proença LAO, Monserrat JM (2005) Antioxidant responses and oxidative stress after microcystin exposure in the hepatopancreas of an estuarine crab species. Ecotox Environ Safe 61:353-360. https://doi.org/10.1016/j.ecoenv.2004.11.014.

Prione LP, Olchanheski LR, Tullio LD, Santo BCE, Reche PM, Martins PF, Carvalho G, Demiate IM, Pileggi SAV, Dourado MN, Prestes RA, Sadowsky MJ, Azevedo RA, Pileggi M (2016) GST activity and membrane lipid saturation prevents mesotrione-induced cellular damage in Pantoea ananatis. ABM Express 6:70. https://doi.org/10.1186/s13568-016-0240-x.

Ren Q, Zhao R, Wang C, Li S, Zhang T, Ren Z, Yang M, Pan H, Shiguo Xu, Zhu J, Wang X (2017) The role of ache in swimming behavior of Daphnia magna: Correlation analysis of both parameters affected by deltamethrin and methomyl exposure. J Toxicol 2017:11. https://doi.org/10.1155/2017/3265727. 
Soler ET, Del Rio JG, Vives F (1988) Morphological and taxonomical revision of Centropages

771 ponticus Karavaev, 1895 (Copepoda, Calanoida). Crustaceana 55: 129-146.

772 https://doi.org/10.1163/156854088X00474.

773 Sousa CA, Soares HMVM, Soares EV (2018a) Nickel oxide (NiO) nanoparticles induce loss of cell

774 viability in yeast mediated by oxidative stress. Chem Res Toxicol 31:658-665.

775 https://doi.org/10.1021/acs.chemrestox.8b00022.

776 Sousa AC, Soares HMVM, Soares VE (2018b) Toxic effects of nickel oxide (NiO) nanoparticles on the

777 freshwater alga Pseudokirchneriella subcapitata. Aquat Toxicol 204:80-90.

778 https://doi.org/10.1016/j.aquatox.2018.08.022.

779

780

781

782

783

784

785

786

787

788

789

790

791

792

793

794

795

796

797

798

799

800

801

802

803

804

805

806

807

808
Sukhanova A, Bozrova S, Sokolov P, Berestovoy M, Karaulov A, Nabiev I (2018) Dependence of nanoparticle toxicity on their physical and chemical properties. Nanoscale Res Lett 13:44. https://doi.org/10.1186/s11671-018-2457-x.

Tadik M, Nikolic D, Panjan M, Blake GM (2015) Magnetic properties of NiO (nickel oxide) nanoparticles: Blocking temperature and neel temperature. J Alloy Compd 647: 1061-1068. https://doi.org/10.1016/j.jallcom.2015.06.027.

Wang Z, Zhao J, Li F, Gao D, Xing B (2009) Adsorption and inhibition of acetylcholinesterase by different nanoparticles. Chemosphere 77: 67-73. https://doi.org/10.1016/j.chemosphere.2009.05.015.

Wiesner MR, Lowry GV, Alvarez P, Dionysiou D, Biswas P (2006) Assessing the Risks of Manufactured Nanomaterials. Environ Sci Technol 40: 4336-4345. https://doi.org/10.1021/es062726m.

Wong SWY, Zhou GJ, Leung PTY, Han J, Lee JS, Kwok KWH, Leung KMY (2020) Sunscreens containing zinc oxide nanoparticles can trigger oxidative stress and toxicity to the marine copepod Tigriopus japonicus. Mar Pollu Bull 154:111078. https://doi.org/10.1016/j.marpolbul.2020.111078.

Zhang M, Yang J, Cai Z, Feng Y, Wang Y, Zhang D, Pan X (2019) Detection of engineered nanoparticles in aquatic environment: 2 state-of-art and challenges in enrichment, separation and analysis. Environ Sci Nano 3: 1-78. https://doi.org/10.1039/C8EN01086B.

Zhou C, Vitiellol V, Casals E, Puntes VF, Iamunno F, Pellegrini D, Wu C, Benvenuto G, Buttino I (2016) Toxicity of nickel in the marine calanoid copepod Acartia tonsa: nickel chloride versus nanoparticles. Aquat Toxicol 170: 1-12. https://doi.org/10.1016/j.aquatox.2015.11.003.

Zhou C, Carotenuto Y, Vitiello V, Wu C, Zhang J, Buttino I (2018) De Novo Transcriptome Assembly and Differential Gene Expression Analysis of the Calanoid Copepod Acartia Tonsa Exposed to Nickel Nanoparticles. Chemosphere 209:163-172. https://doi.org/10.1016/j.chemosphere.2018.06.096. 
810 Fig. 1 Aggregates of nickel oxide nanoparticles (NiO NPs) visible by microscopy 811 after $48 \mathrm{~h}$ in (a) on urosome and furca and (b) on the antennules of the marine 812 copepod Centropages ponticus exposed to $2 \mathrm{mg} / \mathrm{L}$.

813

814 Fig. 2 (a) Effect of nickel oxide nanoparticles (NiO NPs) on egg production rate 815 (eggs/female/day) of Centropages ponticus females after $24 \mathrm{~h}$ and $48 \mathrm{~h}$ and (b) egg 816 hatching success rate (\%) of eggs produced by $C$. ponticus after $24 \mathrm{~h}$ and $48 \mathrm{~h}$. Values 817 shown are mean \pm standard deviation. Letters on bars indicate significant difference 818 between groups (Tukey's post-hoc $p<0.05$ ).

819 Fig. 3 Effects of nickel oxide nanoparticles (NiO NPs) on activity of the enzymes (a) 820 superoxide dismutase (SOD), (b) catalase (CAT), (c) glutathione S-transferase (GST), 821 and (d) acetylcholinesterase (AChE) in adult Centropages ponticus after $24 \mathrm{~h}$ and 48 822 h. Values shown are mean \pm standard deviation. Letters on bars indicate significant 823 difference between groups (Tukey's post hoc test, $p<0.05$ ). 


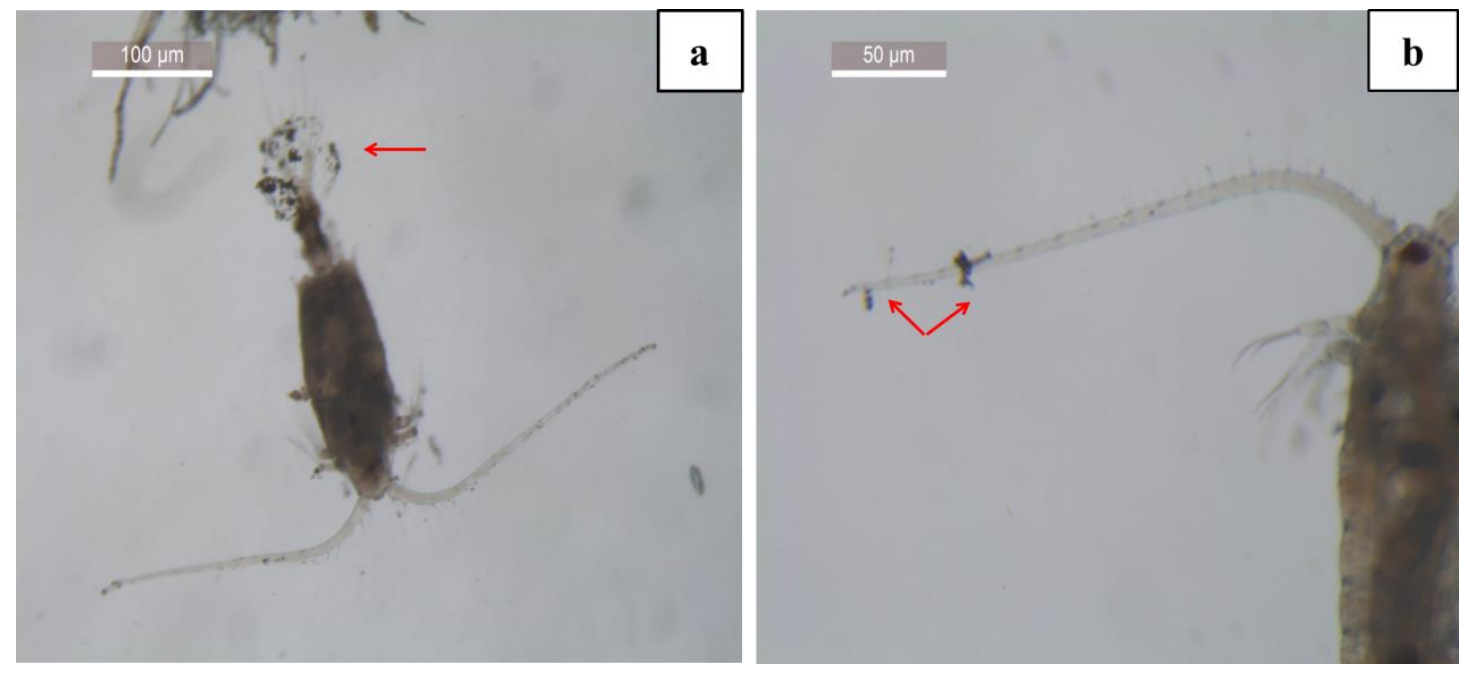

833

834 Fig. 1 Aggregates of nickel oxide nanoparticles (NiO NPs) visible by microscopy 835 after $48 \mathrm{~h}$ (a) on the urosome and furca and (b) on the antennules of the marine 836 copepod Centropages ponticus exposed to $2 \mathrm{mg} / \mathrm{L}$.

837

838

839

840

841

842

843 

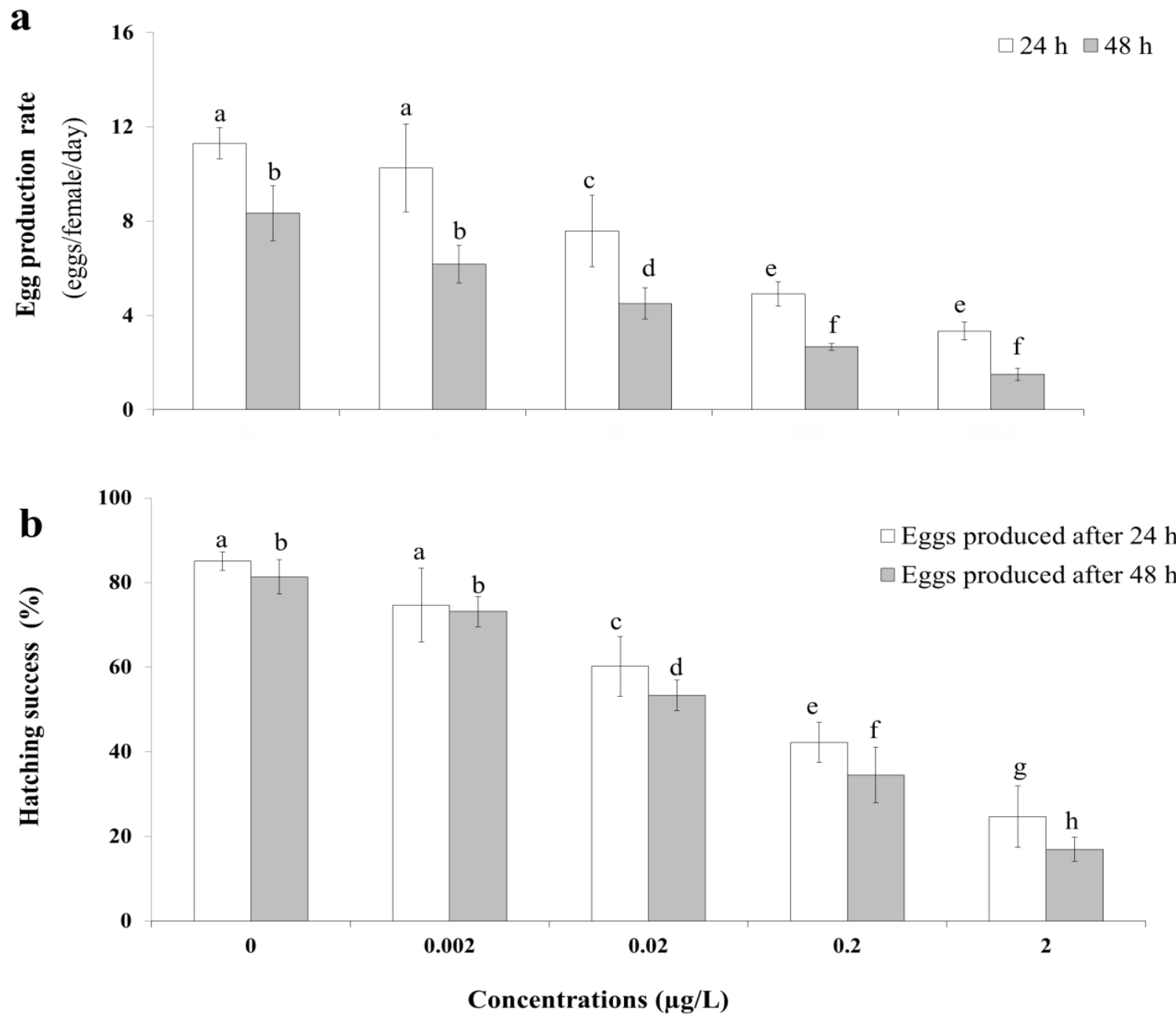

Fig. 2 (a) Effect of nickel oxide nanoparticles (NiO NPs) on egg production rate (eggs/female/day) of Centropages ponticus females after $24 \mathrm{~h}$ and $48 \mathrm{~h}$ and (b) egg hatching success rate (\%) of eggs produced by $C$. ponticus after $24 \mathrm{~h}$ and $48 \mathrm{~h}$. Values shown are mean \pm standard deviation. Different letters on bars indicate significant difference between exposed $C$. ponticus females and controls (Tukey's post-hoc $p$ $<0.05)$. 
a

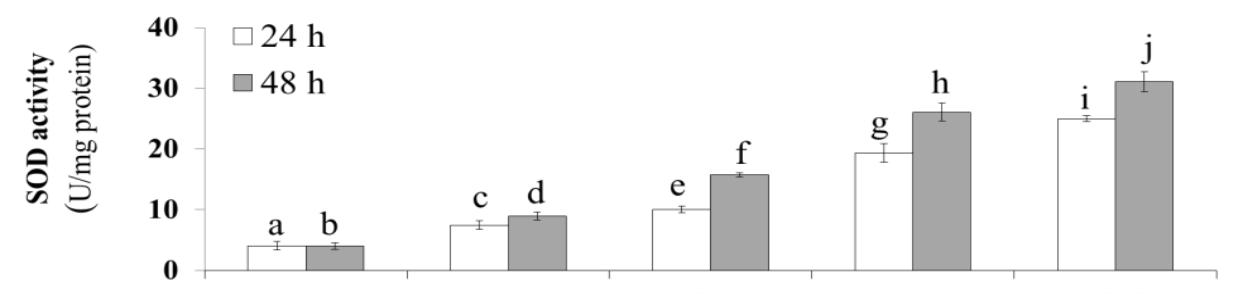

b

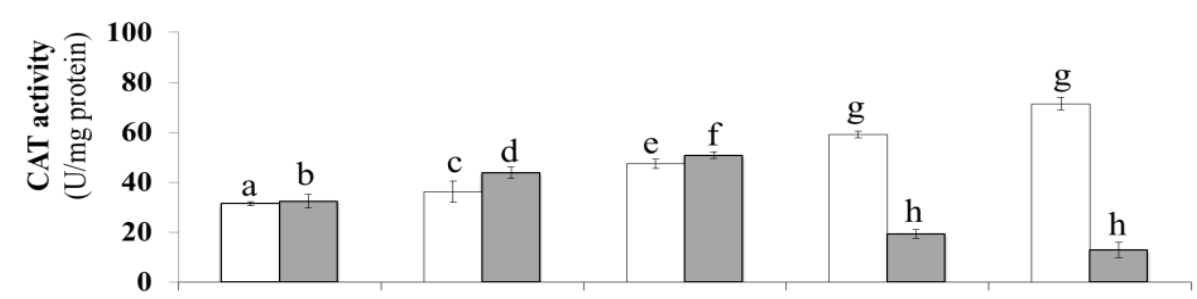

C
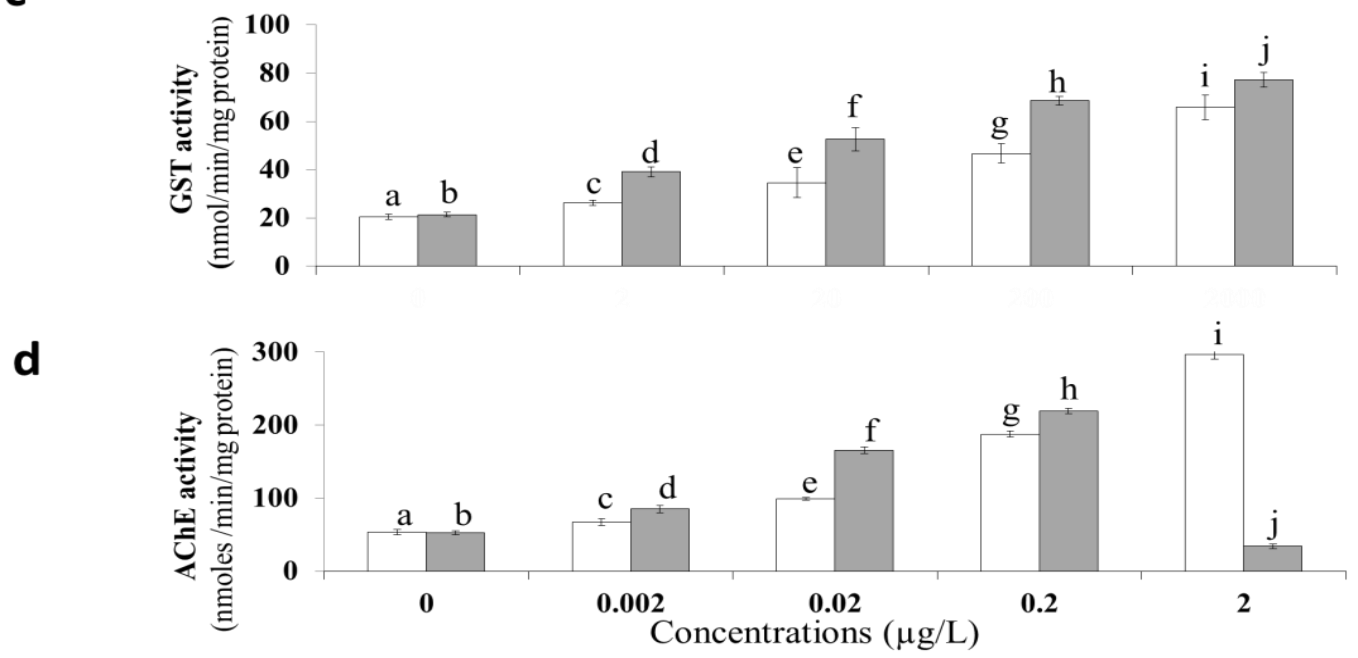

860

861

862

863

864

865 866

867

868

869

870

871

872

Fig. 3 Effects of nickel oxide nanoparticles (NiO NPs) on activity of the enzymes (a) superoxide dismutase (SOD), (b) catalase (CAT), (c) glutathione S-transferase (GST), and (d) acetylcholinesterase (AChE) in adult Centropages ponticus after $24 \mathrm{~h}$ and 48 h. Values shown are mean \pm standard deviation. Different letters on bars indicate significant difference between groups (Tukey's post hoc test, $p<0.05$ ). 
875 Table 1 Synthesis of results of two-way factorial analysis of variance (ANOVA) 876 showing the effects of concentration of nickel oxide nanoparticles (NiO NPs) and 877 time exposure on the different parameters studied in Centropages ponticus: EPR = 878 egg production rate, HS = hatching success, SOD = superoxide dismutase activity, 879 CAT $=$ catalase activity, GST $=$ glutathione $\mathrm{S}$-transferase activity, $\mathrm{AChE}=$ 880 acetylcholinesterase.

881 Table 2 Lethal concentrations ( $\left.\mathrm{LC}_{10}, \mathrm{LC}_{50}, \mathrm{LC}_{70}, \mathrm{LC}_{90}, \mathrm{mg} / \mathrm{L}\right)$ in Centropages 882 ponticus adult females exposed to nickel oxide nanoparticles (NiO NPs) for $24 \mathrm{~h}$ and $88348 \mathrm{~h}$, with associated $95 \%$ confidence intervals (CI).

884 Table 3 Median lethal concentration $\left(\mathrm{LC}_{50}\right)$ of nickel oxide nanoparticles (NiO NPs) 885 in the marine copepod Centropages ponticus and in some other aquatic species.

886 


\begin{tabular}{ccccccccccc} 
Parameter & \multicolumn{3}{c}{ Effect of NiO NP concentration } & \multicolumn{3}{c}{ Effect of exposure time } & \multicolumn{4}{c}{ Concentration $\times$ Time } \\
\cline { 2 - 10 } & $F$ & $d f$ & $P$ & $F$ & $d f$ & $P$ & $F$ & $d f$ & $P$ \\
\hline Survival & 23.93 & 4 & $<\mathbf{0 . 0 0 5}$ & 11.76 & 1 & $<\mathbf{0 . 0 0 5}$ & 3.17 & 4 & $<\mathbf{0 . 0 0 5}$ \\
EPR & 60.85 & 4 & $<\mathbf{0 . 0 0 5}$ & 66.23 & 1 & $<\mathbf{0 . 0 0 5}$ & 1.22 & 4 & 0.333 \\
HS & 130.43 & 4 & $<\mathbf{0 . 0 0 5}$ & 7.61 & 1 & 0.120 & 0.38 & 4 & 0.818 \\
SOD & 454.93 & 4 & $<\mathbf{0 . 0 0 5}$ & 105.20 & 1 & $<\mathbf{0 . 0 0 5}$ & 11.12 & 4 & $<\mathbf{0 . 0 0 5}$ \\
CAT & 40.49 & 4 & $<\mathbf{0 . 0 0 5}$ & 401.38 & 1 & $<\mathbf{0 . 0 0 5}$ & 240.47 & 4 & $<\mathbf{0 . 0 0 5}$ \\
GST & 191.57 & 4 & $<\mathbf{0 . 0 0 5}$ & 101.50 & 1 & $<\mathbf{0 . 0 0 5}$ & 7.50 & 4 & $<\mathbf{0 . 0 0 5}$ \\
AChE & 454.93 & 4 & $<\mathbf{0 . 0 0 5}$ & 105.20 & 1 & $<\mathbf{0 . 0 0 5}$ & 11.12 & 4 & $<\mathbf{0 . 0 0 5}$ \\
\hline
\end{tabular}

Table 1 Synthesis of results of two-way factorial analysis of variance (ANOVA) showing the effects of concentration of nickel oxide nanoparticles (NiO NPs) and time exposure on the different parameters studied in Centropages ponticus: EPR = egg production rate, $\mathrm{HS}=$ hatching success, $\mathrm{SOD}=$ superoxide dismutase activity, $\mathrm{CAT}=$ catalase activity, GST $=$ glutathione $\mathrm{S}$-transferase activity, $\mathrm{AChE}=$ acetylcholinesterase.

894

895

896

897

898

899

900

901

902

903

904

905

906

907 
909 Table 2 Lethal concentrations ( $\left.\mathrm{LC}_{10}, \mathrm{LC}_{50}, \mathrm{LC}_{70}, \mathrm{LC} 90, \mathrm{mg} / \mathrm{L}\right)$ in Centropages

910 ponticus adult females exposed to nickel oxide nanoparticles (NiO NPs) for $24 \mathrm{~h}$ and

$91148 \mathrm{~h}$, with associated 95\% confidence intervals (CI).

912

$$
\text { Exposure duration } \quad \mathrm{LC}_{10}(95 \% \mathrm{CI}) \quad \mathrm{LC}_{50}(95 \%) \quad \mathrm{LC}_{70}(95 \% \mathrm{CI}) \quad \mathrm{LC}_{90}(95 \% \mathrm{CI})
$$

$\begin{array}{lllll}\mathbf{2 4} \mathbf{h} & 4.29(2.64-6.96) & 13.83(8.52-22.44) & 22.33(13.762-36.2) & 44.6(27.59-72.33)\end{array}$

$48 \mathrm{~h}$

913

914

915

916

917

918

919

920

921

922

923

924 
Table 3 Median lethal concentration ( $\mathrm{LC}_{50}$ ) of nickel oxide nanoparticles (NiO NPs) in the marine copepod Centropages ponticus and in some other aquatic species.

\begin{tabular}{|c|c|c|c|c|}
\hline Species & $\begin{array}{c}\text { Freshwater / } \\
\text { marine } \\
\text { species }\end{array}$ & Endpoint Test & $\mathbf{L C}_{50}$ & References \\
\hline $\begin{array}{l}\text { Chlorella vulgaris } \\
\text { (microalga) }\end{array}$ & \multirow{6}{*}{$\begin{array}{l}\text { Freshwater } \\
\text { species }\end{array}$} & $\begin{array}{c}96 \text { h EC50 (NiO NPs } 30 \\
n m)\end{array}$ & $13.7 \mathrm{mg} / \mathrm{L}$ & $\begin{array}{l}\text { Oukarroum et al. } \\
\text { (2017) }\end{array}$ \\
\hline $\begin{array}{l}\text { Danio rerio } \\
\text { (zebrafish) } \\
\text { adults }\end{array}$ & & $\begin{array}{c}48 \mathrm{~h} \mathrm{LC}_{50}(\mathrm{NiO} \text { NPs }<50 \\
\mathrm{nm}) \\
\begin{array}{c}96 \mathrm{hLC}_{50}(\mathrm{NiO} N \mathrm{NPs}<50 \\
\mathrm{nm})\end{array}\end{array}$ & $\begin{array}{l}760 \mathrm{mg} / \mathrm{L} \\
420 \mathrm{mg} / \mathrm{L}\end{array}$ & $\begin{array}{l}\text { Kovrižnych et al. } \\
\text { (2013) }\end{array}$ \\
\hline $\begin{array}{l}\text { Danio rerio } \\
\text { adults }\end{array}$ & & $\begin{array}{l}30 \text { day } \mathrm{LC}_{50}(\mathrm{NiO} N \mathrm{NPs} \\
<50 \mathrm{~nm})\end{array}$ & $45 \mathrm{mg} / \mathrm{L}$ & $\begin{array}{l}\text { Kovrižnych et al. } \\
\text { (2014) }\end{array}$ \\
\hline $\begin{array}{l}\text { Danio rerio } \\
\text { eggs }\end{array}$ & & $\begin{array}{c}96 \mathrm{~h} \mathrm{LC}_{50}(\mathrm{NiO} \text { NPs }<50 \\
\mathrm{nm})\end{array}$ & $1300 \mathrm{mg} / \mathrm{L}$ & $\begin{array}{l}\text { Kovrižnych et al. } \\
\text { (2013) }\end{array}$ \\
\hline \multirow[t]{2}{*}{$\begin{array}{l}\text { Daphnia magna } \\
\quad \text { cladoceran) } \\
\text { neonates }(<24 \mathrm{~h})\end{array}$} & & $\begin{array}{c}\text { Immobilization (NiO } \\
\text { NPs }<50 \mathrm{~nm}) \\
48 \mathrm{~h} \mathrm{LC}_{50}\end{array}$ & $36.79 \mathrm{mg} / \mathrm{L}$ & Gong et al. (2016) \\
\hline & & $\begin{array}{c}\text { Immobilization } \\
24 \mathrm{~h} \mathrm{LC}_{50}(\mathrm{NiO} \text { NPs } 100 \\
\mathrm{nm}) \\
48 \mathrm{~h} \mathrm{LC}_{50}(\mathrm{NiO} 100 \mathrm{~nm}) \\
24 \mathrm{~h} \mathrm{LC}_{50}(\mathrm{NiO} N \mathrm{NPs} 10- \\
20 \mathrm{~nm}) \\
48 \mathrm{~h} \mathrm{LC}_{50}(\mathrm{NiO} N \mathrm{NP} 10- \\
20 \mathrm{~nm}) \\
\end{array}$ & $\begin{array}{c}14.6 \mathrm{mg} / \mathrm{L} \\
9.74 \mathrm{mg} / \mathrm{L} \\
13.98 \mathrm{mg} / \mathrm{L} \\
9.76 \mathrm{mg} / \mathrm{L}\end{array}$ & Nogueira et al. (2015) \\
\hline $\begin{array}{l}\text { Centropages } \\
\text { ponticus } \\
\text { (copepod) } \\
\text { adults }\end{array}$ & \multirow{2}{*}{$\begin{array}{l}\text { Marine } \\
\text { species }\end{array}$} & $\begin{array}{c}24 \mathrm{~h} \mathrm{LC}_{50}(\mathrm{NiO} \mathrm{NPs}<50 \\
\mathrm{nm}) \\
48 \mathrm{~h} \mathrm{LC50}\end{array}$ & $\begin{array}{l}13.85 \mathrm{mg} / \mathrm{L} \\
4.07 \mathrm{mg} / \mathrm{L}\end{array}$ & Present study \\
\hline $\begin{array}{l}\text { Leptocheirus } \\
\text { plumulosus } \\
\text { (amphipod) }\end{array}$ & & $\begin{array}{c}10 \text { day } \mathrm{LC}_{50}(\mathrm{NiO} \text { NPs13 } \\
\mathrm{nm})\end{array}$ & $\begin{array}{c}\text { No mortality } \\
\text { at } \geq 2000 \\
\mu \mathrm{g} / \mathrm{g}\end{array}$ & Hanna et al. (2013) \\
\hline
\end{tabular}

